Article

\title{
New Housing Concepts: Modular, Circular, Biobased, Reproducible, and Affordable
}

\author{
Leo Oorschot ${ }^{1} \mathbb{D}$ and Thijs Asselbergs ${ }^{2, *}$ \\ 1 1M Homes Initiative, Department of Management in the Built Environment, Faculty of Architecture and the \\ Built Environment, Delft University of Technology, 2628BL Delft, The Netherlands; leooorschot@hotmail.com \\ 2 1M Homes Initiative, Department of Architectural Engineering \& Technology, Faculty of Architecture and the \\ Built Environment, Delft University of Technology, 2628BL Delft, The Netherlands \\ * Correspondence: m.f.asselbergs@tudelft.nl
}

Citation: Oorschot, L.; Asselbergs, T. New Housing Concepts: Modular, Circular, Biobased, Reproducible, and Affordable. Sustainability 2021, 13, 13772. https://doi.org/10.3390/ su132413772

\section{Academic Editors:}

Giouli Mihalakakou, Dušan Katunský and Stanislav Darula

Received: 28 October 2021

Accepted: 9 December 2021

Published: 14 December 2021

Publisher's Note: MDPI stays neutral with regard to jurisdictional claims in published maps and institutional affiliations.

Copyright: (C) 2021 by the authors. Licensee MDPI, Basel, Switzerland. This article is an open access article distributed under the terms and conditions of the Creative Commons Attribution (CC BY) license (https:/ / creativecommons.org/licenses/by/ $4.0 /)$.

\begin{abstract}
For a moment, it seemed that the architect had disappeared from the construction supply chain for sustainable and affordable housing provided by Dutch housing associations. Large contractors were making direct agreements with housing associations and wanted to scale up production with their housing factories. However, with the 'So You Think You Can BUILD' challenge, architects, consultancies, and contractors reinvented themselves within the construction supply chain and acquired a position as providers of circular building concepts. The aim of this challenge is to stimulate providers of homes to design and produce (in great numbers) affordable and sustainable houses. This not only scales up building production in empty fields but also within difficult and dense build urban areas. A whole new generation of Dutch architects, consultancies, and contractors working in collaboration are now intensively involved with circular and biobased residential buildings, innovative materials and production processes. They are managing to provide attractive products for housing associations and other clients. In the first part of 2021, 'So You Think You Can BUILD' challenged teams of designers, engineers and contractors to develop new concepts, with the three winners applying the principles of the 'passive house', which is modular and circular, as well as a smart building skin and smart core with open floor space in between.
\end{abstract}

Keywords: affordable housing; housing crisis; circular economy; energy transition; conceptual houses; modular houses; smart homes; The Netherlands

\section{Introduction: Affordable Housing through a Continuous Stream of Assignments}

This contribution is about an industry challenge in the first part of 2021 in the Netherlands. The idea behind the So You Think You Can BUILD [1] competition was to challenge providers of homes to come up with a sustainable, circular, affordable housing concept that could supply housing in great numbers for one or two people and improve the total-cost-of-ownership (TCO) over 50 years for the housing association.

This was in the context of a shortage of dwellings in the Netherlands and the government's intention in its 'National Strategy on Spatial Planning and the Environment' ('Nationale Omgevingsvisie', NOVI,) to create one million new sustainable homes by 2030 [2].

However, the problems to be addressed were more complex. Professor Housing Systems of Delft University of Technology Peter Boelhouwer address seven of the foremost important problems related to the housing crisis: (i) there is a home shortage due to ongoing migration to urban areas and rapid growth of the urban population generally, as well as the increasing number of sole occupancy houses; (ii) there is a housing cost problem since the income of people is insufficient for the rents being asked; (iii) the position of newcomers or people on a middle income in the housing market is weak since sufficient dwellings are not available and buying is not an option, meaning that the housing market is divided into 'insiders' and 'outsiders'; (iv) sufficient housing for the elderly has not been organized or built, meaning there is a gap between what people want 
and what is built; (v) there is no flow of tenants, with older people living as singles or couples in family-sized homes; (vi) there is a concentration of people living in poverty or on low incomes in neighbourhoods where the housing stock is in the hands of housing associations that provide affordable homes to people based on their income, and in this context, making homes available is complex and expensive, with housing associations having a limited investment capacity for renovation or demolition and the building of new homes; and finally (vii) that there is the problem of weak foundations, with much stock in the Netherlands built on peat meadows, meaning many old dwellings require expensive renovation [3].

After the elections of 2020, the debates about the housing crisis and the climate crisis were linked and new solutions were expected. This led to a consortium of 34 stakeholders, including housing association umbrella organizations, real estate developers, building contractors and municipalities publishing a programme calling for the new government to take action [4]. Many articles and opinions about this programme subsequently appeared in journals and it was incorporated into the ambitions of NOVI. However, little affordable and sustainable housing was planned or built as a result.

This article does not intend to elaborate further on the Dutch housing shortage and the country's sustainability ambitions but rather, with this context in mind, to describe a challenge presented to home providers to find solutions to this wicked problem. The research, design and engineering work were carried out by the home providers and the article describes the outcomes and deliberations of the selection committee of the challenge.

The organizers of the challenge were the 'Netwerk Conceptueel Bouwen' (NCB) [5], ten housing associations and Aedes [6]. NCB is a knowledge network consisting of government, the construction industry, education and research institutions, while Aedes is the umbrella organization of housing associations in The Netherlands. The aim of the challenge was 'Affordable housing through a continuous stream of assignments', as Harry Platte, CEO of a housing association and member of the NCB board pointed out [7]. Due to rising construction costs, they started looking for opportunities to build differently, not in a traditional way but rather in a conceptual one using modular products produced in factories. They wanted to achieve innovations in the standardization of homes and production processes to stimulate imminent building production in urban regions. Aedes and NCB spoke of conceptual building in factories and the end of traditional building on the construction site.

Below, we first describe the definitions, terms, method, challenges, organization, and our aims. Second, we present the three winners of the challenge. Third, we describe the characteristics of a modular buildings system in general. Fourth, we examine the debate within the selection committee and jury about the entries. Finally, we draw some conclusions.

\section{Definitions, Terms, Method, and Challenge}

\subsection{What Is a Dwelling According to Dutch Housing Associations?}

In 2018, NCB started collaboration with Aedes and developed a standards framework 'De Woonstandaard' [8] with which it formalized performance agreements between housing associations (clients) and contractors (concept providers) using a generic programme of performance requirements for all kinds of homes. The range of building concepts was digitally visualized and ordered according to Product-Market-Combinations (PMCs) on the digital 'Conceptenboulevard' [9], as described in 'De Woonstandaard'. NCB and Aedes intended to bundle the demand through 'De Woonstandaard' and the house building initiative 'De Bouwstroom' [10] and implement new concepts to realize the upscaling of Dutch housing production in the coming years. This will streamline construction and development costs, reduce failure costs for everyone and reduce overall costs.

'De Woonstandaard' describes basic quality in the form of Product-Market-Combinations (PMC) with which the demand of housing associations is aligned with 'supply' by the construction industry. The goal of these PMCs is to build affordable, usable and sustainable 
homes. The basic quality and additional performance are described for four categories of dwellings: single-family dwellings, units in a multi-storey apartment building, temporary housing and small units with shared facilities ('onzelfstandige woningen'). These categories are each divided according to the size of the dwelling and five rental price classes. Altogether, there are thus 20 different PMCs. The current 'Woonstandaard' describes 14. On 1 October 2020, the first webinar on the 'Bouwstroom' was held at Delft University of Technology [11]. A PMC is the basic quality in seize. This quality is defined ad user quality, technical and aesthetic quality, health and environment quality. A PMC is used as contract between housing association and contractor. PMC1 to 5 are ground-level homes in five rental categories, PMC6 to 10 are apartments in a residential building in five categories, and PMC15 to 20 are dependent units for students.

\subsection{Terms and Definitions}

An affordable home is a dwelling for which the rent is set in accordance with the Dutch Home Valuation System (Woningwaarderingsstelsel, WWS). The WWS is a point system that evaluates the dwelling and determines the maximum rent on this basis, or whether it should not be included in the affordable housing stock. Different aspects are considered, such as floor space, number of rooms, energy performance and location [12]. The categories 1 to 4 (Figure 1) are affordable homes, while PMC5 and PMC10 are not in the affordable stock according to the WWS, and are part of the 'free' rental market. The maximum rent in 2021 for affordable housing was set at $€ 752.33$ a month.

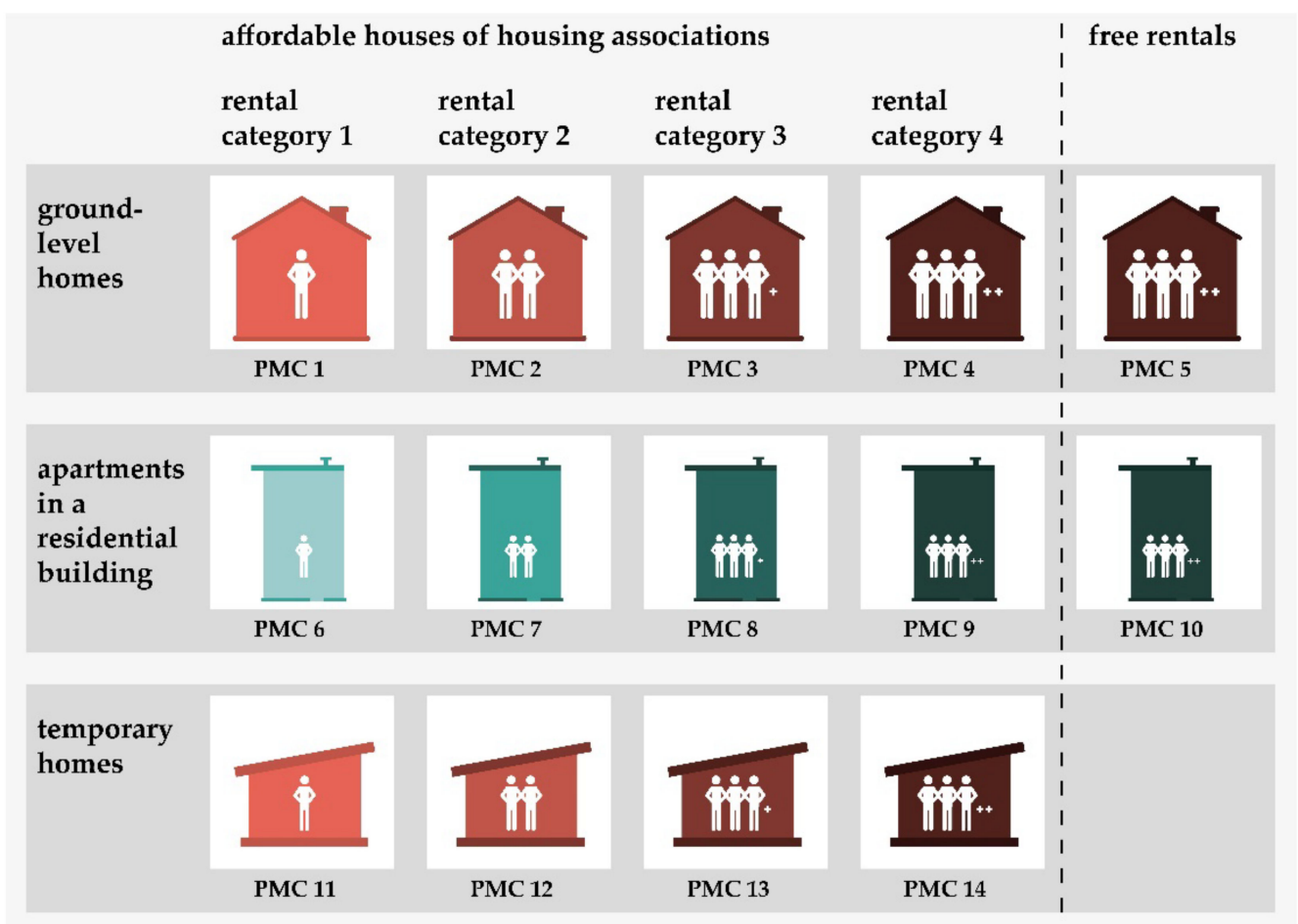

Figure 1. 'De Woonstandaard' with 14 independent dwellings of the 20 basic types, or PCM's. Type 15 to 20 are dependent student units. Source: NCB website.

The Dutch governmental institute NEN has an online dictionary on the circular economy, with all definitions and terms [13]. Furthermore, all terms and definitions dealing with circular construction are defined in the Lexicon Circular Construction (2020). The English version of the Lexicon Circular Construction was created by Platform CB'23, with unambiguous terms and definitions [14]. These terms and definitions are used by the Dutch Transition Team and its website, 'De Circulaire Bouweconomie' (CBE), which has representatives from the government, consultancies, institutes, umbrella organizations, banks and universities. 
In the Lexicon, 'circular construction' is defined as developing, using and reusing buildings, areas and infrastructure without unnecessarily depleting natural resources, polluting the living environment or affecting ecosystems. It concerns construction that it is economically justifiable and that contributes to the welfare of people and wildlife, in all places and in the present and future. 'Circular structure' is defined as one designed and constructed according to circular design principles and/or constructed using circular products, elements and materials. 'Circular economy' is defined as an economic system that optimizes the use and value of resource flows without hampering the functioning of the biosphere and the integrity of society. This means endeavoring to protect biological and technical stocks of materials, avoiding environmental impacts and preserving existing value.

The 'environmental performance of buildings' (MPG) summarizes the environmental costs per gross floor area and measures the sustainability of a building in terms of net energy consumption and environmental burden based on the materials used. The MPG is calculated according to the SBK determination method. An MPG score is required when applying for an environmental permit for new-build homes and office buildings of more than $100 \mathrm{~m}^{2}$. 'Environmental cost' is defined as the financial interpretation of any negative environmental impact resulting from the design, construction and use of a structure.

In addition, the Lexicon also lists and defines many other terms such as 'raw materials', 'operating cost', 'lifespan', 'reduce', 'redesign', 'recycle', 'recover', 'reclamation', 'refuse', 'renew', 'renovate', 'remanufacture', 'repair', 'repurpose', 'rethink', 'reuse', 'primary and secondary materials', 'sustainable', 'life cycle cost', 'total cost of ownership' (TCO), 'building passport', 'biobased construction and materials.'

The terms 'innovative' and 'conceptual' were introduced by Aedes and NCB in relation to their 'construction stream' ('Bouwstroom') programme. 'Conceptual construction' is the opposite of the 'traditional construction' of homes on a plot. 'Conceptual' is defined as the production of a already existing home concept in a factory prior to any plot location. With the term 'innovative', Aedes and NCB intends to stimulate providers of homes to create new housing concepts according to their requirements.

\subsection{Research through Design (RTD) as Methode}

The method used to achieve the goal of innovative, conceptual construction relies on research through design (RTD). RTD involves scientific inquiry, with proposals taking advantage of the unique insights gained through design and production practices to provide a better understanding of complex design and production issues [15-17]. The first step in fostering conceptual construction through RTD was developing a framework, which was done by NCB and Aedes. The second step was inviting providers of homes to take up the new building challenge. The third step involved the assessment of the designs by a committee of specialists from housing associations, consultancies and universities. The fourth step was the selection of six proposals by the jury. The fifth step was a presentation by the candidates and a public debate with the jury and the six candidates. The jury then chose three of the six proposals in the final step.

Both design and research are activities that are typically initiated with a contextspecific purpose. In this case, the Dutch context was most relevant, but the entries demonstrate that the providers also drew on concepts from Germany, Japan and the UK. One significant current problem is the fragmentation of knowledge, because of the separation of design and production, and the resulting lack of design solutions. From the perspective of RTD, the entries to the challenge can be considered case studies, with the committee thus implementing an empirical investigation of a phenomenon within a real-life context. This provided multiple sources of evidence and the opportunity to expand on and generalize the theory. Thus, the RTD method allowed us to test the framework of NCB and Aedes and demonstrate the possibilities of conceptual homes under real-life conditions. Validation of the framework and the design strategies will be done by building the winning concepts. 
This is not the first time in the Netherlands that such a challenge has been used to achieve such goals. The 'Goedkoope arbeiderswoningen' ('Affordable workers' housing') challenge was organized by the municipality of Amsterdam in 1936. It marked the starting point for a completely new attitude in architecture, with a focus on the design and production of affordable housing and better urban planning. As a result, many architects and engineers who were unknown before the Second World War became leading designers and producers of post-war modern architecture [18].

Another challenge was organized in 2009 by the municipality of Groningen and real estate developers. Under the title, 'Intense Laagbouw. Woningbouw in hoge dichtheden' ('Intensive low-rise building: high-density residential construction'), this challenge concerned the possibility of creating urban ensembles with a high density of dwellings [19]. Both challenges led to many feasible solutions for architects, urban planners, real estate developers, housing associations and municipalities. They are also both well documented in publications in a line of books on good, affordable housing, which has a long tradition in the Netherlands. One of the first appeared in 1921, authored by Berlage, Keppler, Kromhout and Wils, presenting examples of affordable homes constructed according to new legislation [20].

In keeping with this tradition, the framework and the aim of the challenge in 2021 was to come up with innovative, affordable and circular housing concepts that could provide dwellings in great numbers for housing associations. The problem for housing corporations was that almost no new dwellings for one to two people in the types PMC2 and PMC7 had been built, primarily since the total-cost-of-ownership (TCO) or the operating costs of the building during its lifecycle, was too high. However, the demand for housing for this target group was and is very high in the Netherlands. Criteria for the entries were: a TCO of 50 years; purchase costs and affordability; failure, operating and maintenance costs; options in design, implementation, possession, financing and operation; cooperation with partners in the construction supply chain; energy and environmental performance; quality and the potential to be built in great numbers. Furthermore, the focus was on three types of dwellings for one to two people with a rent below $€ 634$ (price level January 2021): PMC2, standard row house; PMC2, row house life-course-proof; and PMC7, multi-storey apartment buildings. In short, a real challenge. Participants submitted many attractive and feasible concepts, which are now presented on the 'Conceptenboulevard', a gallery of examples available on the internet.

\subsection{The Candidates for the Challenge}

Today, there are many companies in The Netherlands that are intensively engaged in innovative building concepts [21], such as 'Jan Snel'; 'Nimbel'; 'SQL-Pulchram Group'; 'Koopmans Bouwgroep/TBI' with the 'HOUTbaar' concept; 'Homes Factory' with a 3-D modular construction system; 'Ekowood Houses'; 'Finch Buildings'; 'Barli'; 'Plug \& Play Housing' with modular, biobased and circular concepts; 'CyBe Construction' and 'RS Housing' both with factory produced units; 'Van der Heijden Bouwbedrijf' with the 'WISH 4 Future' concept; the 'Radiodomus' concept of 'Atriensis innovation' and 'elk ${ }^{\circledR}$,; 'Genius Homes' and 'BAM Wonen', with their concept dwellings and many more. In short, there is plenty to choose from for housing associations that want to scale up with 'De Bouwstroom'.

From 94 entries, the selection committee and jury selected 6 finalists after a long debate. For multi-storey apartment buildings (PMC7), they chose 'Elk-TransforMEER' by the company 'elk ${ }^{\circledR \circledR}$ ' and 'MOOS' by the company 'In The Middle Of Our Street'. For regular row houses (PMC2), they chose 'Leven-Buiten-de-Lijntjes' by the company, 'Dura Vermeer', and 'Tala-NERF' by the company 'Tala'. For the life-course-proof row houses (PMC2), they chose 'Slimmer-Wonen' by 'Jan Snel' and 'Uuthuuske' by 'The New Makers'. Each of the finalists explained their concept in a public pitch, which was followed by a critical interrogation by the jury and public [22]. After deliberation, the winners were finally chosen. The three winners were 'MOOS' (PMC7), 'Leven-Buiten-de-Lijntjes' (PMC2) and 'Uuthuuske' (PMC2). 
Although the challenge called for 'innovative building concepts', most of the entries were concerned with factory-produced modular residential units designed to meet all the set criteria. It appeared that the era of traditional construction on site with its concomitant nitrogen emissions, plagued by a shortage of labour and wet assembly of components, is slowly coming to an end. The circular economy is on the horizon.

\section{Innovative Building Concepts Turn out to Be Modularly Produced}

\subsection{Uuthuuske-the New Makers}

'Uuthuuske' has all the ingredients to be a truly modular, circular, biobased and affordable concept for row houses [23]. A dwelling can consist of several modules as Figures $2-4$ show. This start-up is supported by one of the big construction companies in The Netherlands. The team of 'The New Makers' shows that there is real construction supply chain integration here. One third of the employees are architects, who are mainly focused on the requirements of the users; one third are engineers, who are concerned with architectural and construction innovations; and one third are the makers who produce the modules. The construction is carried out by three robots in a factory. The robots, Scarlett, Rover, and Dyna, produce a kind of Ikea-like kit in the factory. Co-makers assemble that kit on the building site. A one-day course suffices to learn how to assemble the kit since it can easily be clicked together. The modules are completely biobased. Due to the use of wood, the house has a healthy and vapour-open indoor climate while the wood also stores $\mathrm{CO}_{2}$ from the atmosphere.
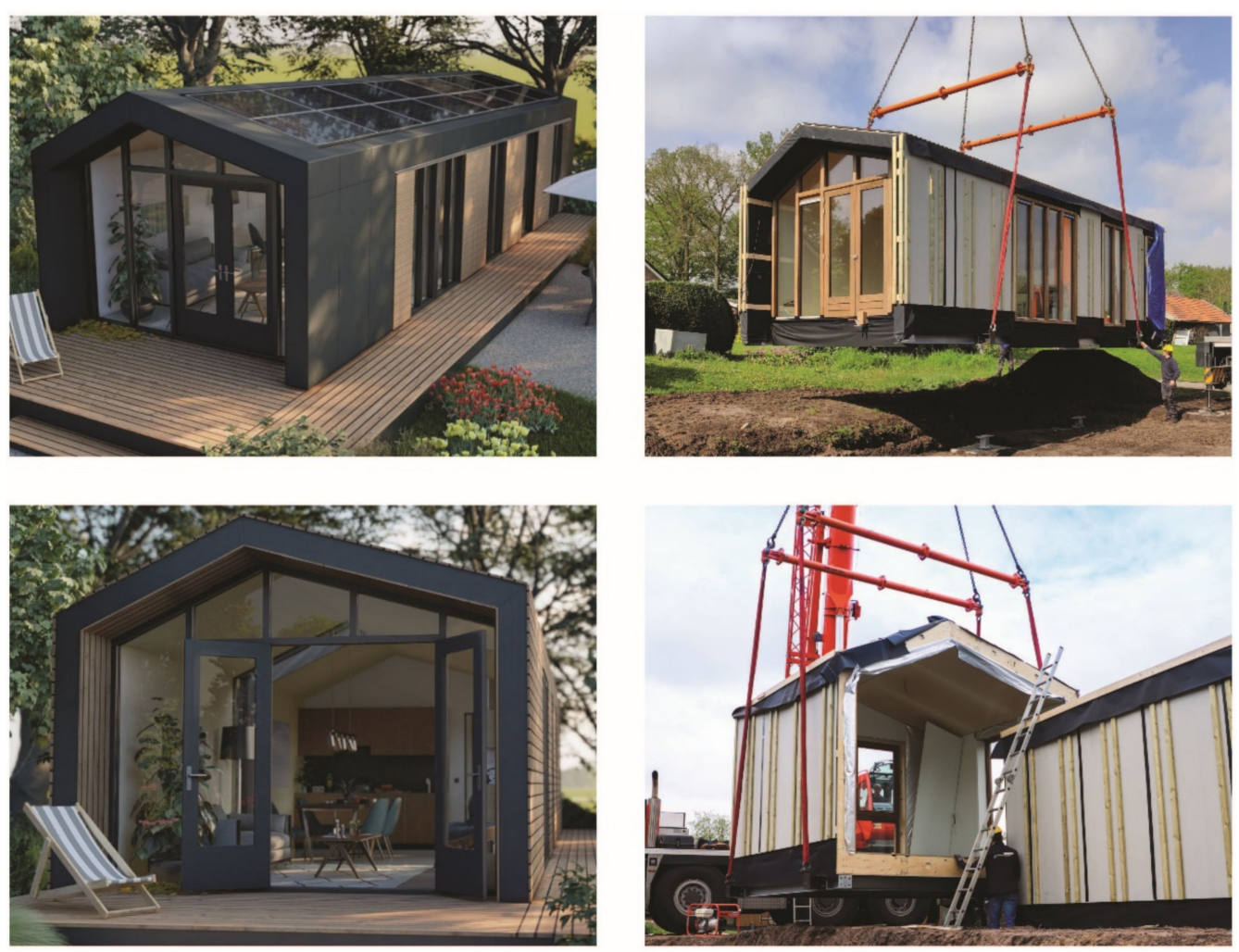

Figure 2. Uuthuuske: modular, circular, biobased, flexible, affordable. Source: The New Makers. 

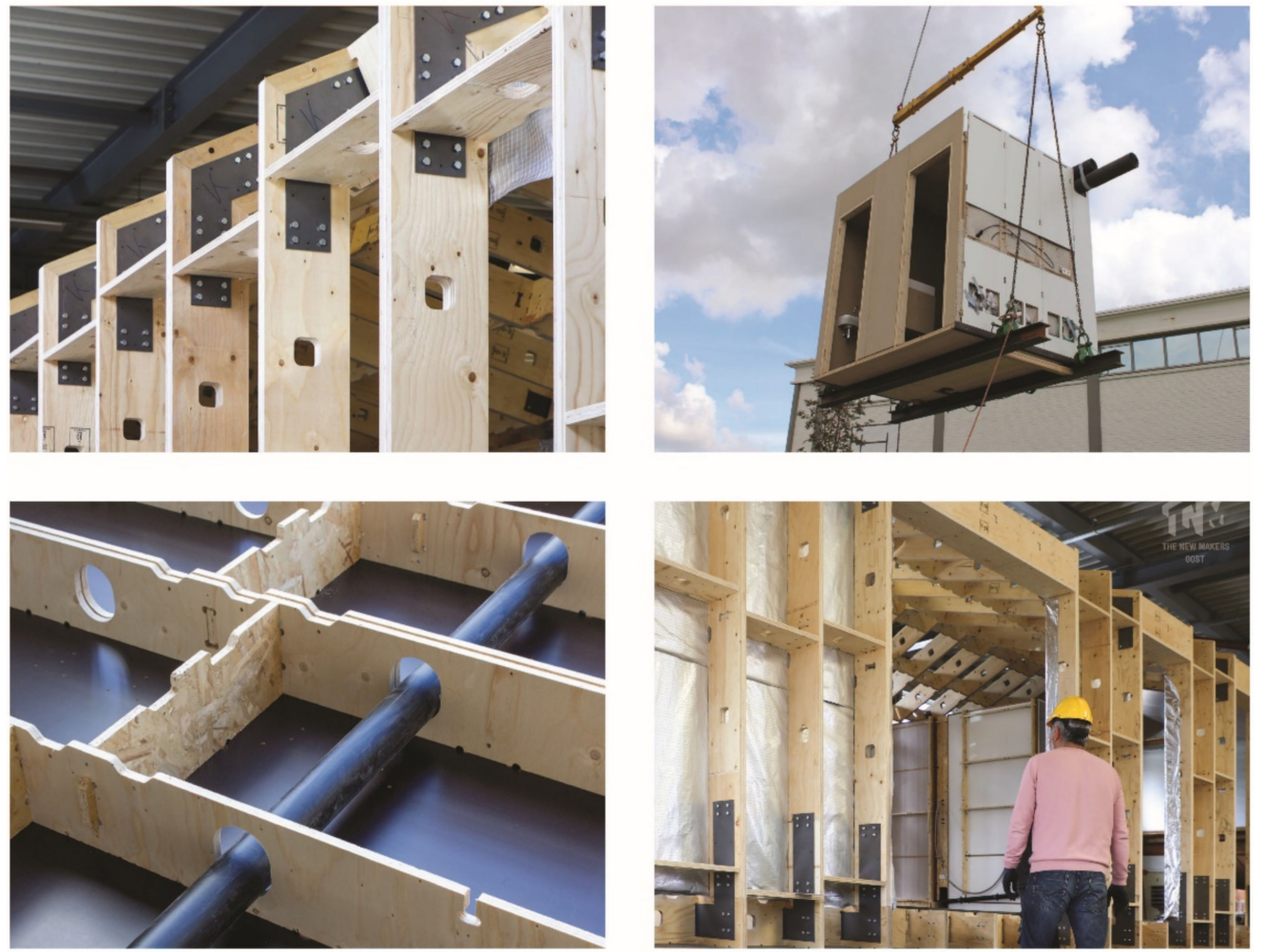

Figure 3. Uuthuuske produced in the factory. Source: The New Makers.

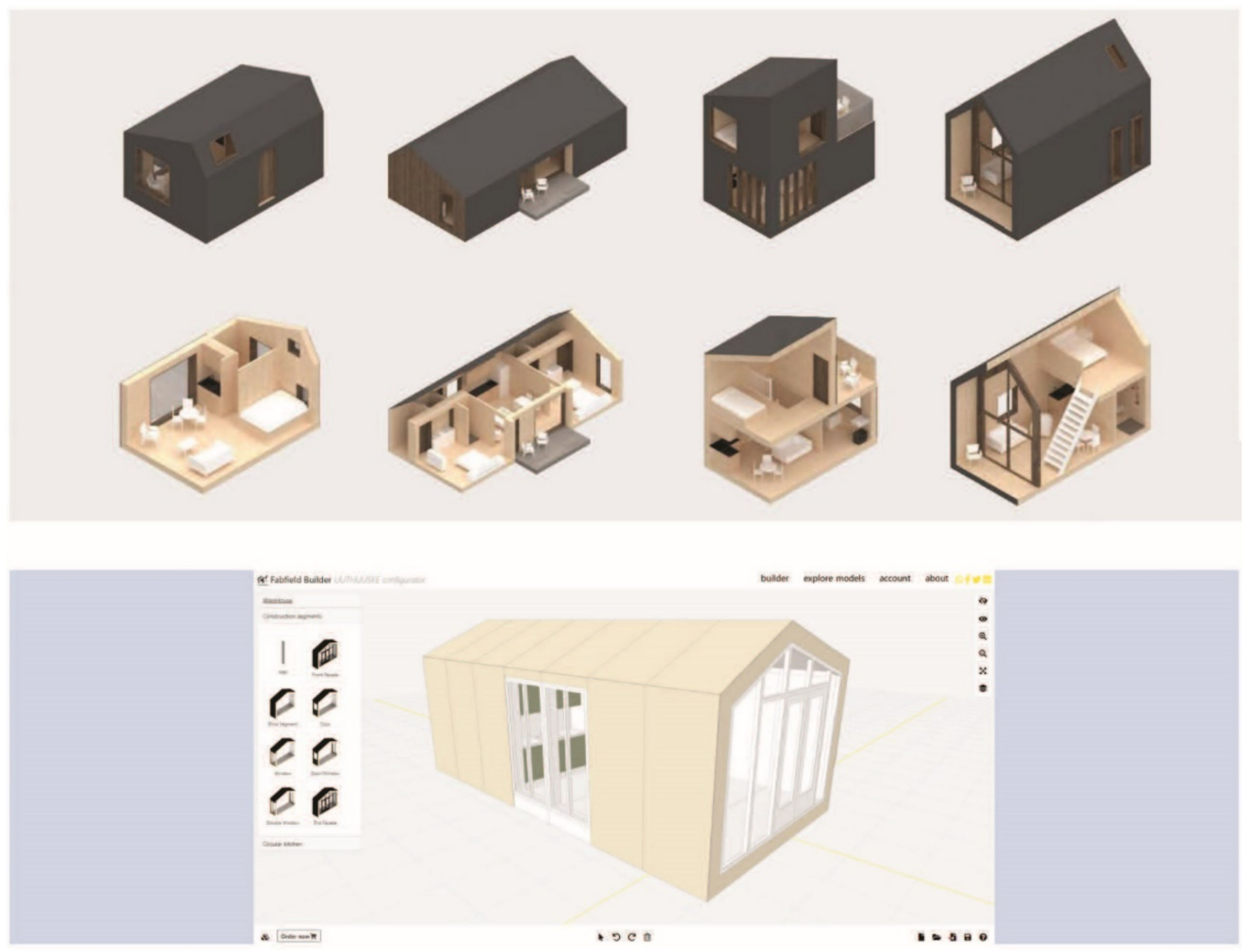

Figure 4. Uuthuuske designed with the configurator tool. Source: The New Makers.

One point of attention in relation to the use of all timber is the risk of temperature overruns in the summer, with the potential for overheating and heat stress due to solar radiation, internal heat load, and degree of ventilation. The 'New Makers' worked intensively 
on this problem, with hybrid service systems, balanced ventilation, heat recovery and cooling. The Uuthuuskes are all electric (do not rely on gas) and offer different variants for heating and ventilation. Infrared radiant panels and an air-to-air heat pump are mentioned. Decentralized heating and ventilation by means of a Climarad system is also possible. PV panels on the roof are possible. The plug and play service systems are certified and from another supplier. One other important component of Uuthuuskes is the 'comfort cabin', a compact block with kitchen, bathroom and toilet, into which all plug and play service systems are integrated. A circular NOWA kitchen is installed in this cabin [24].

Uuthuuskes are flexible in various ways. By using digital techniques, customization for specific residents is combined with mass production. This is possible since the modules are entirely made up of subcomponents that can be assembled by anyone who understands an Ikea manual. Due to the demountability of all subcomponents and service systems, there is a wide variety of choices for the user, which can also be adjusted in the future. The modules are movable and can be easily transported. Subcomponents can be clicked together by users, for example an inner wall. An infinite variety of floor plans is possible. Also, the facade can be adapted to local requirements (for example, a municipality might want timber or brick in specific neighbourhoods). The houses can be switched into clusters or configurations and research is being conducted into stackable modules. The modules are easy to move elsewhere if the plot is needed for something else. For municipalities, this offers the possibility of having them as temporary flexible living spaces for urgent home seekers.

\subsection{MOOS-in the Middle of Our Street}

The start-up 'In the Middle Of Our Street' intended to provide an answer to the climate problem and the housing shortage with MOOS [25]. They did this by means of robust stacked buildings made of industrially produced modules with a flexible and hybrid construction system, circular concrete used in floors, and cross-laminated timber (CLT) walls as Figures 5 and 6 show.
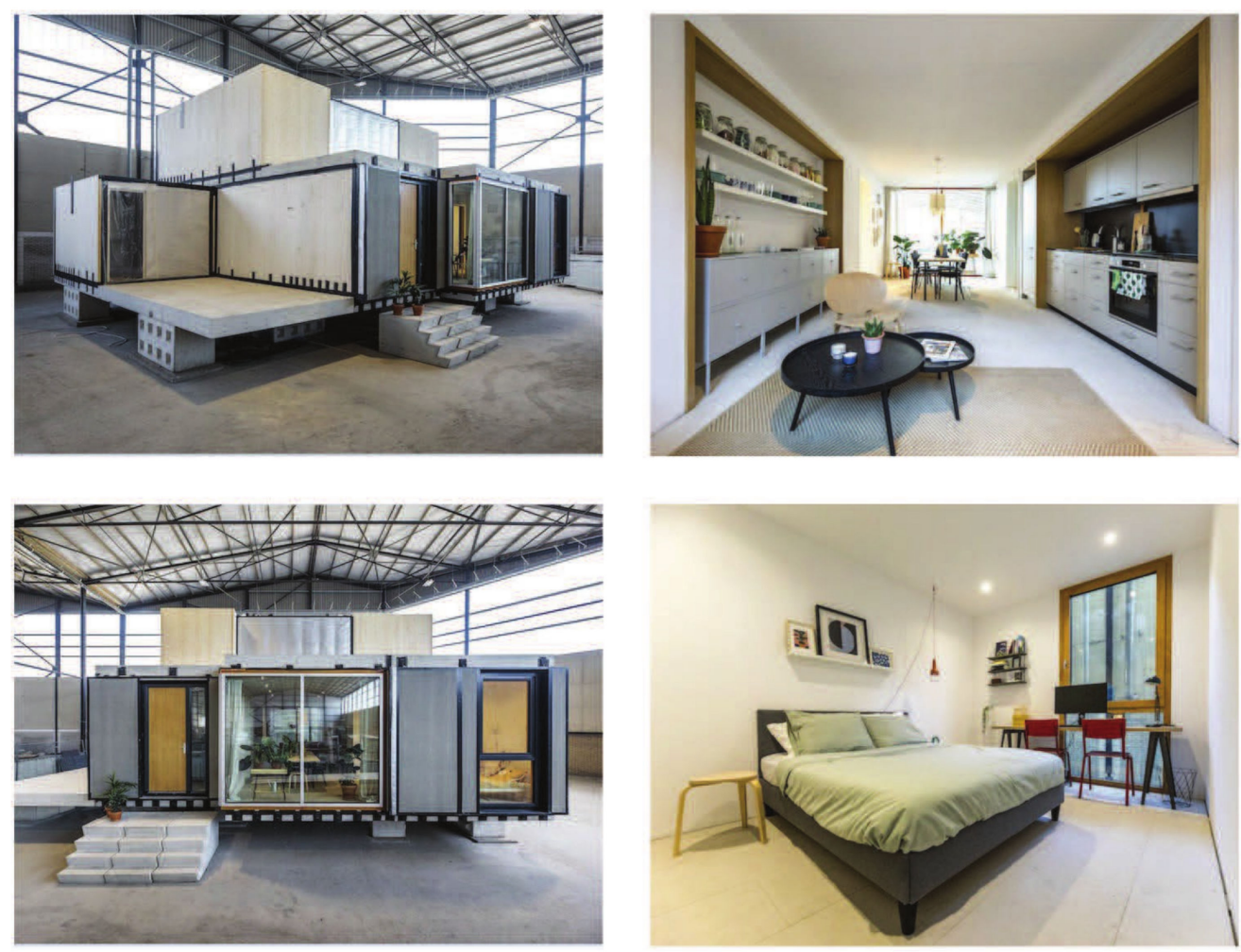

Figure 5. Left above and below, a mock-up of three MOOS modules. Right above and below, the interior of the living module and the sleeping module. Source: In the Middle of Our Street. 

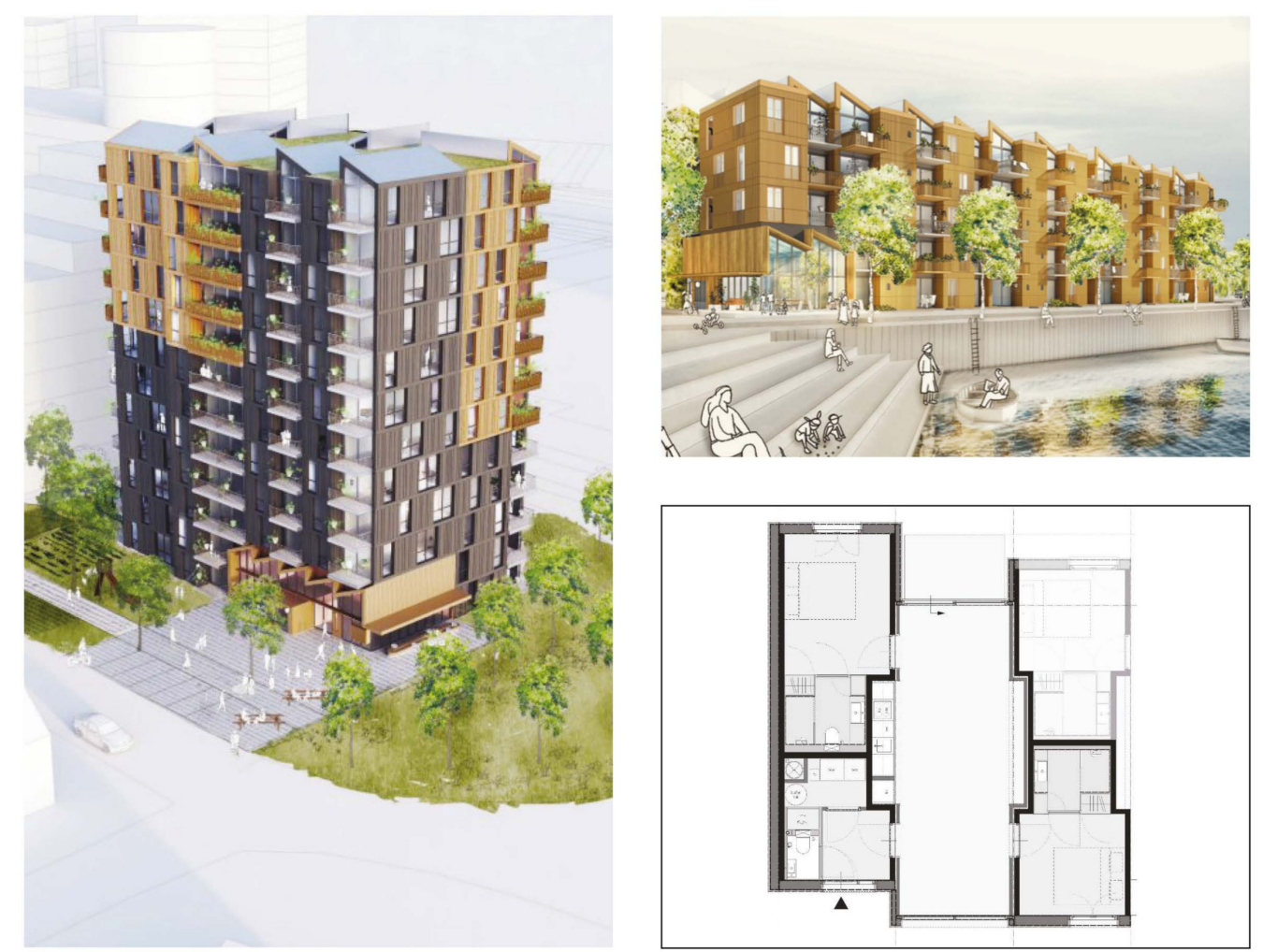

Figure 6. Left, MOOS as multi-storey apartment building up to $70 \mathrm{~m}$ height. Right above, a multistorey building without a lift. Right below, three different modules of MOOS. Source: In the Middle of Our Street.

In The Middle of Our Street works as a general contractor with a network of partnersthe partner ecosystem. A sketch design is made in two to three hours with a building configurator before the partners assemble their semi-finished products in the MOOS assembly plant into complete homes. All partners bear responsibility for price, quality and planning of their components. The design and production models are merged using building information modelling (BIM), which integrates structured, multi-disciplinary data to produce a digital representation of an asset across its lifecycle, from planning and design to construction and operations. Due to the integrated working method of a multidisciplinary team of designers, engineers, suppliers and builders, a high-quality product is delivered and the failure costs are reduced.

There are several raw material flows that are used in the production of the modules. First of all, materials derived from demolition are provided by a sister company and partner, New Horizon Urban Mining (especially the circular concrete). The second raw material flow is biobased material, the CLT walls, and ceiling. In collaboration with its partner New Horizon, In the Middle of Our Street constantly looks for donor buildings that can supply the raw materials for elements such as the facade. In addition, the client, such as a housing association, is often the third source, supplying the raw materials themselves if they are demolishing homes. Facade materials can therefore be adapted.

The future-proof construction method has loose floors with complete freedom of layout, placed between a base module. There is a basic module with kitchen, bathroom, toilet, storage room, entrance, and bedroom. There is also a living module with complete freedom of layout. In addition, there is an extra module with two bedrooms and two bathrooms. All service systems are located and integrated into the basic modules. Each module can be easily transported.

A great diversity of dwellings is possible depending on the configuration of the modules (for young and old users; from studios of $30 \mathrm{~m}^{2}$ to apartments of $120 \mathrm{~m}^{2}$ ). With these modules, MOOS is able to realize row houses, apartments and residential towers up 
to $70 \mathrm{~m}$ high. In their multi-storey apartment buildings, MOOS offers a shared entrance with functions such as a shop to promote a sense of safety and comfort for the residents. This is an additional common space and is taken into account in the TCO.

The 'passive house principle' is the starting point for MOOS. It consists of having a compact building, very good insulation, triple glass, airtightness and minimal thermal bridges. Again, it relies solely on electric and there are possibilities of individual or collective heat systems. There is balanced ventilation with heat recovery and a fan coil unit for extra heating. In the collective system, there is a heat pump with air, soil, or water as a source of heat. For the individual system, each home has its own heat pump linked to the heat-back-win system. By adding building mass to concrete floors, the dwellings remain cooler in the summer and fire and noise requirements are more readily met. Above all, this hybrid construction allows stacking up to $70 \mathrm{~m}$ high.

\subsection{Living Outside the Lines-Dura Vermeer}

Dura Vermeer was originally a contractor but was wise enough to engage designers and engineers within the company and to come up with a very special product, for which the chain integration of designers, engineers, and makers is far-reaching [26]. They created a smart core that can be used in row houses, apartments, transformation projects or in tiny houses. To consistently separate the building structure and the infill, allowing a real open-planned building was a good start, as Figures 7 and 8 show.
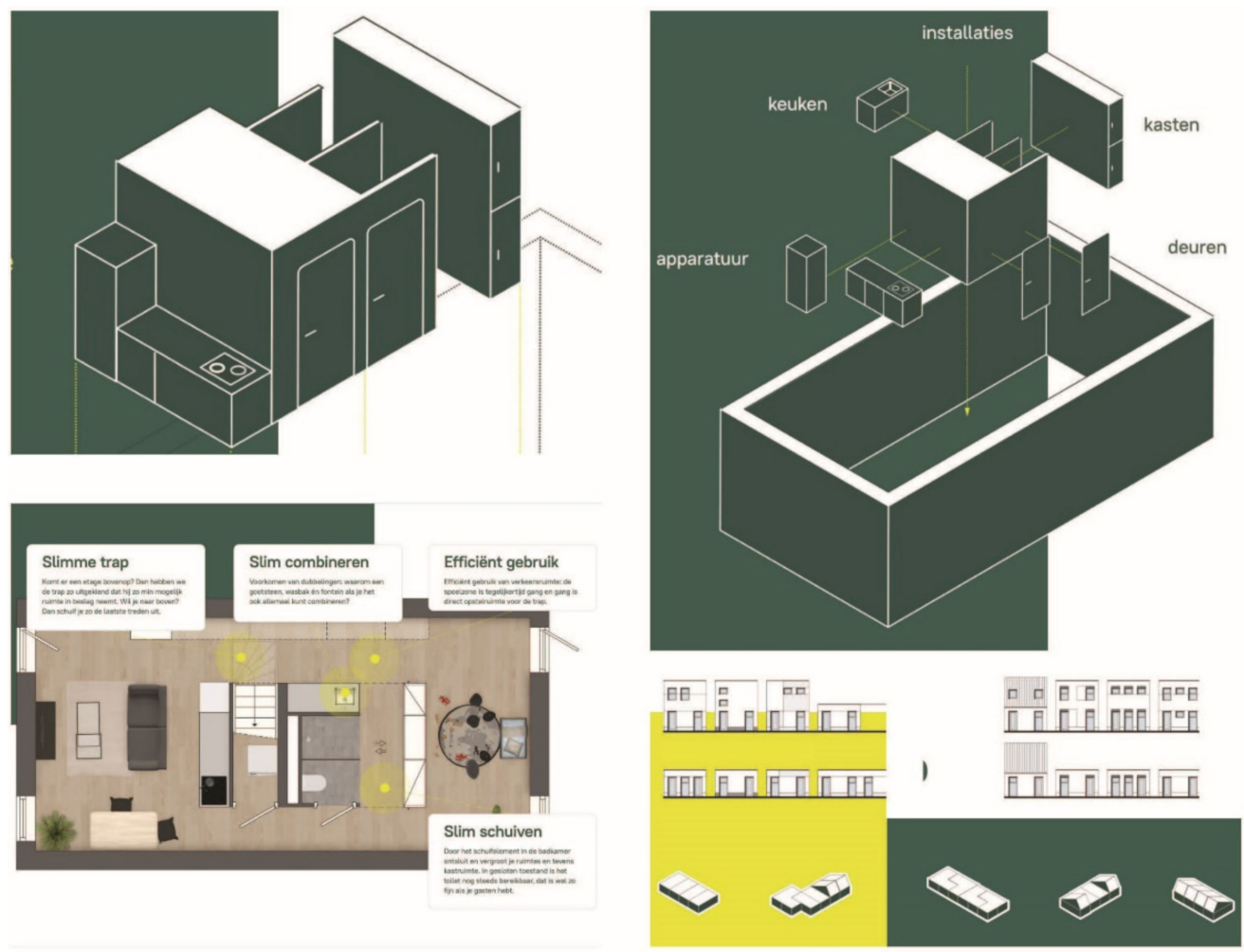

Figure 7. The smart prefab core and the flexible living space around it makes this modular unit special. Source: Dura Vermeer. 


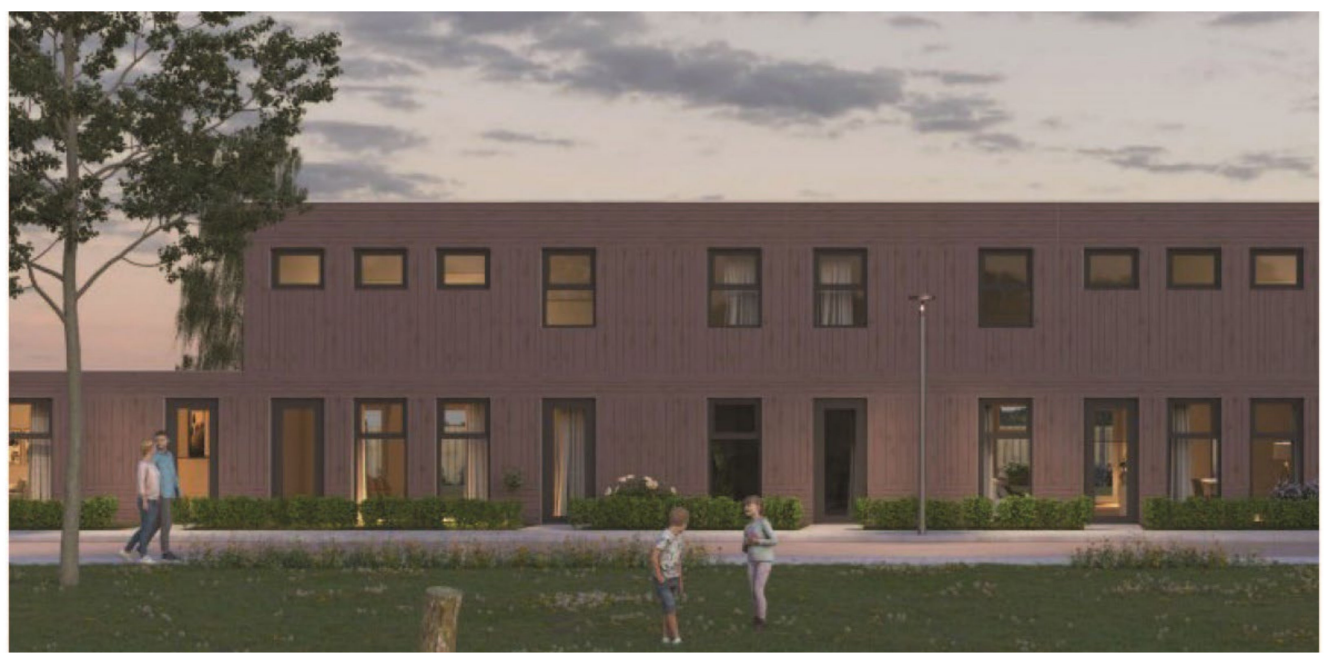

Figure 8. The modules are available in numerous configurations with different facades. Source: Dura Vermeer.

It started with Dura Vermeer rethinking what living actually is. The inspirations were the tiny house movement, community living, and the manufacturing industry, in which production processes have been significantly improved. For Dura Vermeer, living represents space to live.

Regulations are usually based on dividing a dwelling into boxes or spaces next to each other: a box for living, a box for the kitchen, a box for a bedroom, etc. However, when these boxes merge, there is suddenly much more space to live in the dwelling. The lines between the boxes are erased. This gave Dura Vermeer maximum living comfort with a minimum number of square metres (i.e., reduce!)

As with the two previous winners, the dwelling consists of a fully prefabricated core, with a kitchen, bathroom, toilet, storage room, and all service systems integrated into it. Residential functions are grouped around this core. As a result, row housing types can actually be made as well as multi-storey apartment buildings. The flexibility is optimal, with a minimum number of square metres. This prefabricated smart core is also cleverly made. By sliding a wall of the core, one can make the bathroom larger and the living room smaller, and vice versa. The stairs are in the core between the bathroom and kitchen, and the last quarter of the stairs can turn inwards so that there is passage space. If there is no second floor, the stairway space is used for storage. In fact, the dwelling is a tiny house with a smart core, cleverly conceived by the designers. This produces a very compact and therefore affordable dwelling.

The service systems are basic: exhaust ventilation using natural supply via a selfregulating ventilation grill with $\mathrm{CO}_{2}$ controlled mechanical discharge and an exhaust air outlet. The low temperature underfloor heating and the tap water are linked to a ventilation heat pump without an outdoor unit. Optionally, solar panels could be placed on the roof.

The building structure could take any form, but in this case the apartment block has a rib cassette floor on the ground floor, hollow core slab floors on the first floor and prefab walls that are attached with dry connections. However, concrete will also offer much better environmental performance in the future. As New Horizon showed, with low $\mathrm{CO}_{2}$ concrete it will last considerably longer and the building mass can accumulate heat and cold much better than timber. This is an advantage over timber dwellings which can have a heating problem. Furthermore, it is easy to stack the apartments and noise and fire safety standards can be easily met.

\section{What Are the Characteristics of Modular Building Systems?}

Of special interest are the conceptual similarities between all the entries, especially since the criteria were rather ambitious and the challenge was for the brightest minds of the 
building industry to explore the limits of what is possible. These conceptual characteristics also reflect how producers have responded to the challenge of their clients, NCB and Aedes. There are a number of conclusions to be drawn about the characteristics of modular building systems and therefore about 'conceptual construction'.

\subsection{Design and Construction Supply Chain Management}

The place of the architect, the consultants, and the contractor in the construction supply chain has changed, as Professor Hans Wamelink demonstrated in a presentation on 1 October 2020 [27]. Collaborative work within a multidisciplinary team has become necessary to achieve truly affordable and circular construction products and dwellings with climate neutral energy performance, environmental performance using circular materials and a healthy indoor climate, especially during the summer. Many innovative conceptual homes are being produced by a network of companies, each with its own specialty. Providers of circular modules have their own designers who are intensively engaged in designing and producing. Architects, consultants, or contractors no longer work directly on behalf of the client but are involved in a network of providers of the conceptual products. The subcontractors, engineers and architects thus support producers of certified products or services. The far-reaching supply chain integration of the flow of goods, information and money in the construction industry is therefore striking, with design, engineering, and production now interacting and even merging.

BIM plays an important role in this. The designers configure the design for the client and create a design model, engineers work that into a production model, manufacturers produce the units in factories, and finally it is assembled on the construction site. This no longer occurs in strict succession, one step after the other, as in traditional building. The traditional watershed between architect and builder that was formalized by the European Public Procurement Law, in which architects 'provide services' and builders 'carry out works' is thus coming under pressure. If the client wants to have a really attractive circular building, they often opt for a design and build tender.

\subsection{Architecture without a Spatial Context}

The modular concepts are all movable and designed independently of a specific spatial context, but they can be configured into numerous urban ensembles (from terraced houses to multi-storey apartment buildings; from small clusters to residential neighbourhoods). The dwellings may be realized on spacious building plots in large quantities but can also be divided over several small plots in a neighbourhood. Depending on the municipality requirements with respect to the architectural quality of a neighbourhood, different facade materials can be applied. The issue of whether to build only in empty fields or in high densities in urban regions has been separated from the issue of which production system to apply: traditional or conceptual building. In the past, it was thought that conceptual building was only possible in great numbers in empty fields. However, as the keynote speakers and the debate between government architect Floris Alkemade and professor of housing systems Peter Boelhouwer recently demonstrated at the conference 1M-Homes [28], the belief that factory-based building means filling polders with uniform family homes is no longer sustainable.

\subsection{Mass Production with Freedom of Choice}

The modular concepts, as the winners show, can be produced in factories using a blueprint similar to the automotive industry. Digitalization and robotization give the clients and/or residents the space for their own interpretation, due to the flexibility in the production process. Platforms are made with a certain house size, urban configuration, facade material and accessories (the interior variants).

There are great advantages in the factory production of these units: the problem of a shortage of skilled labour is resolved; the materialization and detailing of the end product can be much better achieved; the quality check is much better; the individual wishes of 
the client can be directly incorporated into the production programme; the modules are cheaper and can be produced in great numbers due to serial production; there are fewer failure costs; and losses on the construction site are reduced.

Furthermore, in The Netherlands, nitrogen dioxide emissions (NOx) on building sites in the proximity of designated nature reserves is restricted, which makes it all the more necessary to move production and construction to factories.

\subsection{Smart Core with Kitchen, Bathroom, Toilet, Service System}

Most homes are based on a fully prefabricated smart core with kitchen, bathroom, toilet, storage room and an integrated service system for heating, cooling, ventilation and running water: the Comfort Cabin in the Uuthuuske of The New Makers, for example, she Figure 9. The open building concept with sustainable building structure and a flexible infill takes on a new meaning now that many suppliers have started clustering, integrally designing and prefabricating the difficult and expensive kitchen, bathroom, toilet and service systems. Spaces such as the living room and bedrooms are situated around the core. As a result, the size of each dwelling is variable and both the client and end users can have input into the final form, perhaps even expanding the dwelling at a later date. This core can also be applied, for example, in the transformation of offices into apartments.

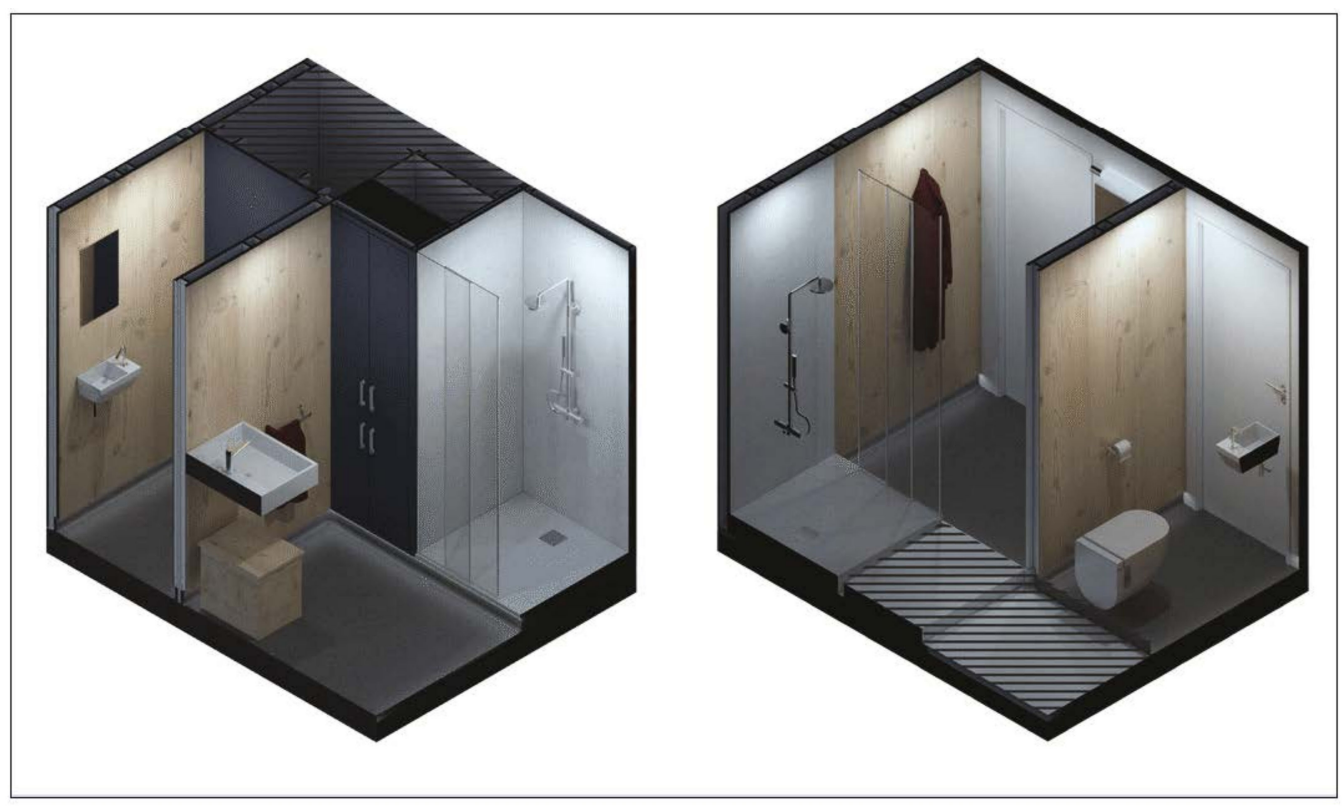

Figure 9. New architecture has a smart facade and smart core with free space in between. The Comfort Cabin in the Uuthuuskes is produced by one of the providers. Source: The New Makers.

\subsection{Hybrid Building Structure in Stacked Construction}

While the modular concept can produce row houses that are completely biobased, for multi-storey apartment blocks there are other requirements concerning fire protection and noise reduction between apartments. Furthermore, there is the mechanical effect of the deformation of wood at high loads. However, a solution is easily found in hybrid construction, with a combination of circular concrete and steel and biobased materials. Often this involves concrete floors and auxiliary steel for concrete structures, in combination with CLT walls that are attached or supported with auxiliary steel. In multi-storey apartment blocks that have mixed functions, such as shops on the ground floor and apartments above, a concrete floor is required by municipalities to ensure fire protection and stability between the different functions. In addition, cores in high-rise buildings with lifts, stairwells, etc. are often used to provide stability to the building, and for this reason steel or concrete must be used. However, as companies such as New Horizon have shown, there is a revo- 
lution going on in the production of circular concrete and the replacement of cement as a raw material.

\subsection{Sustainable Performance of the Modules}

Sustainable performance comprises a combination of factors that can be measured to give an idea of a building's environmental impact during manufacture, use and disposal. In relation to buildings, the factors usually involved provide an indication of the quantity of resources consumed by a building throughout its life and the degree to which its materials can be recycled or reused. While there are many factors, it is necessary to find a balance in performance for three in particular: nearly zero-energy building performance (NZEB); limiting the environmental impact of the (sub)components or (raw) materials of the building (environmental performance buildings; MPG); and a healthy indoor climate (TOjuli). This ideal or balanced coherence depends on the context, situation and location.

With energy performance buildings (or NZEB), the goal is a pleasant indoor climate in the dwelling, in which heating and cooling demand is limited and almost fossil-fuel free. With respect to MPG, the goal is to drastically reduce the environmental impact of the (raw) material and (sub)components used. Reduction of impact is carried out using circular construction methods by, among other things, minimizing the number and use of materials, minimizing building mass, using biobased materials and using demountable components which are easy to replace or reuse. Furthermore, in The Netherlands, the aim is also to minimize activities on the building site to reduce the NOx emissions.

In addressing the indoor climate with wood construction and a minimum building mass, it is important that the risk of temperature exceedance (TOjuli) in the summer is limited. Overheating and heat stress due to solar radiation, heat production inside, and the degree of ventilation are important points for attention. Recently, a determination method and requirements were stipulated in the 'Building Decree' with respect to overheating in new homes (the TOjuli requirement). Timber has less specific mass than concrete and thus requires a different kind of design than concrete.

The factors of energy use, material use, and indoor climate are at odds with each other, but innovative solutions have been devised. Most modules are designed according to 'passive house' principles [29]. Measures include the reduction of energy demand by designing a very compact building, a very well-insulated, triple glass, airtight building skin, and the zoning of spaces in the dwelling into hot and cold. Measures to reduce environmental impact include minimal service systems based on plug and play, and conscious material choices, such as biobased or circular materials. Measures against temperature exceedance include minimum glass surfaces, which are cleverly oriented with shady glass or facades and outdoor sun protection or shutters. The principle here is to absorb the winter sun through the glass and to exclude the hot summer sun.

In The Netherlands, the classic division of the central ventilation system into Types A-C and $\mathrm{D}$ has become problematic, with three sustainability factors partly opposing each other. In general, service systems contribute the most (in a negative sense) to the environmental impact of the building. The division has therefore been extended by a type E decentralized ventilation system for one dwelling with a combined system. In type E, one zone in the dwelling, such as the living room-kitchen-master bedroom, has a mechanical supply and discharge with heat recovery and $\mathrm{CO}_{2}$ control. Heat loss is limited and optimal ventilation is present. Such zoning accords with the principles of the passive house with warmer and cooler spaces. The advantage of type $\mathrm{E}$ is that the maintenance and replacement of filters is simple. The disadvantage is that each separate space which needs to be heated, whether living room or bedrooms, requires a separate unit.

Especially with small units for one to two people, or studios (or other modules where the living space and master bedroom are combined), this is an efficient solution since type $\mathrm{E}$ can be used to ventilate the entire space. To prevent temperature overruns, an active cooling system and adiabatic cooling in ventilation are effective measures. Since active cooling systems use a lot of energy, such as is needed for the compressor of an air heat pump (air 
conditioning), it is better to opt for a cooling (and heating) system based on a bottom heat pump, sustainable cold supply or heat-cold storage such as ATES. The latter only requires electricity for a circulation pump, and possibly a PV panel if the environmental impact allows it. The most efficient modular concepts are all electric with bottom heat pump and low temperature heating/cooling and ATES or a decentralized heating/ventilation system. The building structure is hybrid with circular concrete floors for the building mass, noise insulation and fire safety, a steel frame for the stackability of the modular units and timber walls. There are no complex and costly service systems. If the environmental impact calculations allow it, or if there is enough space on the roof, solar panels are an option.

\section{Discussion of Results and Dilemmas}

As mentioned above, some providers can build multi-storey apartment buildings in high densities in urban regions (e.g., MOOS) or on excess farmland as row houses. They can be clustered in small groups or in urban ensembles in neighbourhoods. Nevertheless, there are a number of dilemmas that became apparent through the 'So You Think You Can BUILD challenge'.

\subsection{Carbon Neutral Energy Use versus Environmental Impact Materials}

Many entrants in the challenge mentioned the environmental performance of buildings without including the service systems or technical building equipment, or they offered different service system options. This raised some difficult problems. For example, solar panels and heat pumps have a high environmental impact in terms of their use of raw materials such as rare metals and the energy required to produce and transport these building components. Currently, service systems with a positive effect on energy performance are also responsible for about $30 \%$ of the total environmental impact of multi-storey apartment buildings. As pointed out, the biggest challenge is to find a balance between the energy performance of buildings, the environmental performance of buildings and a healthy indoor climate during the lifecycle of a multi-storey apartment building. This balance highly depends on the local context and the building components and materials available. While there is no ideal formula, the important factors and methods to calculate the best solution for a situation have been identified. This issue is also debated on the website 'Lente-Akkoord' by several consultancies [30]. Recently, the consultancies of 'W/Eadviseurs' and 'Nieman-de-raadgevende-ingenieurs' published an article that describes the challenges concerning this balance [31]. They emphasized an integrated approach to these three factors when designing multi-storey apartment buildings.

Due to the BREEAM-NL and, in The Netherlands, the GPR-Building certification method, aspects such as energy, environment, health, quality of use and future value are made measurable and comparable and can thus be made coherent and balanced. The principle 'triple bottom line of people-planet-profit', as coined by John Elkington in 1994 [32], is thus given a detailed elaboration in The Netherlands, with calculation methods and sustainable building practices. The concept of sustainability performance buildings (duurzaamheidsprestatie gebouwen DPG), as proposed by 'W/E-adviseurs' and 'TKI-KIEM', offers prospects for an integrated calculation approach to sustainability [33]. This approach is now part of GPR-Buildings and bundles the results of healthy indoor, energy and environmental performance [34]. Passive house solutions offer the best results, with many innovative building concepts making use of this approach. On the one hand, this saves on very expensive service systems and makes the dwellings affordable and, on the other hand, it reduces the environmental impact.

\subsection{Total-Cost-of-Ownership Is Not Standardized and Not Comparable}

Another dilemma is the TCO. For the challenge, the housing associations and NCB required an estimate of the purchase cost and the total-cost-of-ownership (energy costs, maintenance, etc.) for 50 years. Purchase cost is the cost of the building minus the cost of the plot and other costs such as for developing a new building. For the TCO, numerous 
assumptions can be made without knowing whether they will actually eventuate. There was thus a lot of variation in the approach of the providers in the calculation of this cost and the assumptions made about the future. The social context can change rapidly, for example as now with the Covid-19 crisis or the ongoing effects of the climate crisis. Furthermore, technological developments in the coming 50 years may also suddenly offer new possibilities. What was also noted was that energy use by tenants and the purchase costs for housing associations were not integrated into the TCO by anyone. Tenants pay the energy bill and the housing associations invest in the residential buildings. The behaviour of tenants, in particular, has an impact on energy consumption over the long term.

\subsection{The Land Costs and Availability of Plots in Urban Regions Are a Problem}

The land costs were also not taken into account in the challenge. The availability of locations for housing associations in urban regions is often limited. Building plots are not always in the hands of municipalities or housing associations. Real estate developers with a building claim on a plot, or sometimes even municipalities, often have other plans for the plots. With respect to the transformation of a neighbourhood, this usually involves a long process. With respect to the property of housing associations on leasehold land, the transformation of a multi-storey apartment building can still be costly. Often, demolition and soil remediation must first be carried out, residents have to be moved elsewhere and many additional urban amenities and more infrastructure must be built when residential areas are densified. Furthermore, the affordability of housing in attractive locations in urban regions is also problematic since the average tax value or municipal valuation (WOZ) is part of the rent in the Dutch system of determining the rent for affordable dwellings. It is necessary to pay more rent to a housing association in the centre of Amsterdam than in far east of The Netherlands for the same standard of dwelling. The question is whether a dwelling in urban regions with high land prices will ever become affordable, despite the land policies of the municipalities. No matter how innovative and flexible the building concepts are, the local context remains a problem.

\subsection{Recognition of a New Residential Culture Is Lacking in 'De Woonstadaard'}

Another important point is the change in residential culture that is taking place. This has already been partly addressed by designing living concepts for one to two people. However, there is nothing on collaborative housing and other kinds of share concepts in 'De Woonstandaard', which makes it significantly outdated. Are housing associations building the right dwellings for home seekers in the future with 'De Bouwstroom'? For example, are they providing residential buildings where there is a communal kitchen or garden, or clustered units with care for the tenants? Where a car can be shared? Where there is room to work or do homework for the residents of the building? This new residential culture may have an impact on sustainability performance and the TCO, for example, if many more people partly work from home in the future. Fifty years is a long time, and the change in residential culture is moving rapidly now that the housing crisis is affecting increasing numbers of people.

\section{Conclusions and Next Steps}

The promise of the challenge was that the concepts of the winners would be built by housing associations. In general, the capacity for creativity is great, as the challenge showed. With climate-neutral energy management limiting the environmental impact of materials and temperature overrun in the summer, a smart balance can certainly be found. The definition and calculation method of the TCO can also be standardized and formalized such that it becomes comparable, a challenge for NCB, Aedes, and the government. The land value and the housing valuation system can be addressed administratively (if there is a will to do so). Perhaps 'De Woonstandaard' can also be amended and more attention paid to new residential cultures. These are the valuable conclusions of the 'So You Think 
You Can BUILD challenge', which demonstrated the limits but, more importantly, the great potential that the construction supply chain offers.

The next step is the full implementation of the Conceptual Construction ('Bouwstroom') programme, based on an agreement between municipalities and housing associations about the production of affordable and sustainable houses. For example, in the urban region of Haaglanden, in October 2021, the 'Bouwstroom Haaglanden' organization agreed with the province of South Holland, twelve housing associations and eight municipalities in Haaglanden on the construction of 79,000 new homes [35]. Moreover, one of the most important contractors of the Netherlands BAM recently announced that it would cease constructing houses using concrete and, in the future, produce all houses in factories using timber [36]. Recently on GOP 26 in Glasgow, in its 'Green Deal Timber Construction ('Green Deal Houtbouw'), the Metropolitan Region of Amsterdam also decided that by 2025 approximately $20 \%$ of new houses must be biobased [37]. In addition, the limit value of MPG will change from 1 (January 2018) to 0.8 (July 2021) and to 0.5 by 2030. This value is the expression of the environmental impact of new buildings. As the paradigm shift is visible everywhere in the Dutch media today, we might be optimistic that the many promises will become reality in the not too distant future.

Author Contributions: L.O. holds a postdoc position at the $1 \mathrm{M}$ Homes Initiative and is an architect and researcher at atelier PRO architects in The Hague. He was a member of the selection committee of the So You Think You Can BUILD challenge, and conceptualized and wrote this manuscript. T.A. (TU Delft), professor of Architectural Engineering of the Department Architectural Engineering + Technology, was chair of the jury of the So You Think You Can BUILD challenge and supervised the manuscript. L.O. and T.A. are both members of the 1M Homes Initiative of Delft University of Technology. All authors have read and agreed to the published version of the manuscript.

Funding: This research is part of the 1M Homes Initiative of the Delft University of Technology. The $1 \mathrm{M}$ Homes Initiative is an interdisciplinary platform of researchers at the Faculty of Architecture and the Built Environment, which aims to promote the development of knowledge towards an inclusive, affordable, climate friendly and healthy living environment. There was no external funding.

Institutional Review Board Statement: Not applicable.

Informed Consent Statement: Not applicable.

Data Availability Statement: All datasets are digitally available and can be found on the two websites of NCB. All providers to and entries in the So You Think You Can BUILD challenge have been documented and published on the 'Conceptenboulevard' of the NCB. Available online: https:/ / www.conceptenboulevard.nl/ (accessed on 20 July 2021). 'De Woonstandaard' is explained and published on the website of NCB. Available online: https:/ / www.conceptueelbouwen.nl/dew oonstandaard (accessed on 20 July 2021).

Acknowledgments: We would like to thank Marja Elsinga, professor of Housing Institutions \& Governance of the Department of Management in the Built Environment, member of the board of NCB and coordinator of the $1 \mathrm{M}$ Homes Initiative. We would also like to thank the many people who contributed to the debate or made comments on this article, as well as the insights of members of the selection committee: ir. Olga Görts-van de Pas (chair of NCB), ir. Elianne Niyongabo-Paulussen (W/E consultants sustainable building), ir. Thijs Kurstjens (W/E consultants sustainable building), ir. Rick Wielens (Esti), ir. Rogér Gorts (Area Wonen), drs. Rosa Hoogma (In The Middle Of Our street), drs.ir. Tine-Loes Hemmes (Dura Vermeer Bouw Hengelo) and ir. Nadia Remmerswaal (The New Makers).

Conflicts of Interest: The authors declare they have no conflicts of interest. The main funder, TU Delft, had no role in the design of the study; in the collection, analyses, or interpretation of data; in the writing of the manuscript; or in the decision to publish the results. 


\section{References}

1. So You Think You Can BUILD?-ESTI. Available online: https://www.esti.site/soyouthinkyoucanbuild/ (accessed on 20 July 2021).

2. Nationale Omgevingsvisie, Duurzaam Perspectief Voor Onze Leefomgeving. 2020. Available online: https://denationaleomgev ingsvisie.nl/publicaties / (accessed on 20 July 2021).

3. Oorschot, L. Nederland Kantelpunt-Peter Boelhouwer: Interview over 20 Jaar Woningmarkt in Nederland. 2021. Available online: https:/ / research.tudelft.nl/en/publications/nederland-kantelpunt-peter-boelhouwer-interview-over-20-jaar-woni (accessed on 20 July 2021).

4. Samen Werken Aan Goed Wonen. Actieagenda Wonen-17 Februari 2021. Available online: https://aedescms.getbynder.com/m /40d9069ce1416bc6/original/ Actieagenda-Wonen.pdf (accessed on 20 July 2021).

5. Netwerk Conceptueel Bouwen NCB. Available online: https://www.conceptueelbouwen.nl/ (accessed on 20 July 2021).

6. Aedes. Available online: https:/ / www.aedes.nl/ (accessed on 20 July 2021).

7. Aedes \& NCB. Programma de Bouwstroom. Sneller en meer Betaalbare Huizen Bouwen. 2020. Available online: https:/ / dkvwg750av2j6.cloudfront.net/m/28444d436a5adb22/original/Brochure-Programma-De-Bouwstroom-Aedesen-Netwerk-Conceptueel-Bouwen-maart-2020.pdf (accessed on 20 July 2021).

8. NCB. De Woonstandaard. Available online: https://www.conceptueelbouwen.nl/dewoonstandaard (accessed on 20 July 2021).

9. NCB. De Conceptenboulevard. Available online: https://www.conceptenboulevard.nl/ (accessed on 20 July 2021).

10. De Bouwstroom. Available online: https://www.debouwstroom.nl/ (accessed on 20 July 2021).

11. Webinar Bouwstroom 1 Oktober 2020. Available online: https://www.tudelft.nl/bk/over-faculteit/afdelingen/management-inthe-built-environment/organisatie/leerstoelen/publiek-opdrachtgeverschap-in-de-bouw /webinars/webinar-bouwstroom-1oktober-2020 (accessed on 20 July 2021).

12. Cooplink Kennisnetwerk Wooncoöperaties. Available online: https://www.cooplink.nl/wiki/Woningwaarderingsstelsel_(WWS) (accessed on 20 July 2021).

13. Woordenboek Circulaire Economie. Available online: https://www.cewoordenboek.nl (accessed on 20 July 2021).

14. Lexicon Circular Construction Unambiguous Terms and Definitions. 2020. Available online: https://platformcb23.nl/images/d ownloads/PlatformCB23_Lexicon_Circular_Construction_2.0.pdf (accessed on 20 July 2021).

15. Yin, R. Case Study Research: Design and Methods; Applied Social Research Methods Series; SAGE Publications: Thousand Oaks, CA, USA, 1994; Volume 5.

16. Groat, L.; Wang, D. Architectural Research Methods; John Wiley \& Sons: Hoboken, NJ, USA, 2002. Available online: https: //nexosarquisucr.files.wordpress.com/2016/03/architecturalresearchmethods-groat_wang.pdf (accessed on 20 July 2021).

17. Godin, D.; Zahedi, M. Aspects of Research through Design: A Literature Review. In DRS 2014: Design's Big Debates—Proceedings of Design Research Society Conference; Lim, Y.-K., Niedderer, K., Redström, J., Stolterman, J., Valtonen, A., Eds.; Umeå Institute of Design: Umeå, Sweden, 2014; pp. 1667-1679. Available online: https:/ /dl.designresearchsociety.org/cgi/viewcontent.cgi?article $=1012 \&$ context $=$ conference-volumes (accessed on 20 July 2021).

18. Jonker, M. Goedkoope Arbeiderswoningen (1936); Van Gennep: Amsterdam, The Netherlands, 1981.

19. Dorsman, E.; Gameren, D.; Kuitenbrouwer, P.; Schweigman, J.; Verdonk, N. Intense Laagbouw. Woningbouw in Hoge Dichtheden; Platform GRAS: Groningen, The Netherlands, 2009.

20. Berlage, H.P.; Keppler, A.; Kormhout, W.; Wils, J. Arbeiderswoningen in Nederland; W.L.\& J. Brusse's uitgevermaatschappij Rotterdam: Rotterdam, The Netherlands, 1921.

21. Conceptaanbieders. Available online: https: / / conceptenboulevard.nl/aanbieders (accessed on 20 July 2021).

22. Pitch of the Candidates. Available online: https://www.conceptueelbouwen.nl/post/bekijk-de-video-s-van-de-finalisten-so-y ou-think-you-can-build-challenge (accessed on 20 July 2021).

23. The New Makers. Available online: https://thenewmakers.com/product/uuthuuske/ (accessed on 20 July 2021).

24. Comfort Cabin. Available online: https://thenewmakers.com/product/comfort-cabin/ (accessed on 20 July 2021).

25. In the Middle of Our Street. Available online: https:/ / inthemiddleofourstreet.nl/ (accessed on 20 July 2021).

26. Leven Buiten de Lijntjes. Available online: https://www.duravermeer.nl/levenbuitendelijntjes / (accessed on 20 July 2021).

27. Wamelink, H.; Industriële Woningproductie Ontstaat Niet Vanzelf. PowerPoint Presentation. 2020. Available online: https:/ / d2k0ddhflgrk1i.cloudfront.net/BK/Over_de_faculteit/Afdelingen/Management_in_the_Built_Environment/Praktijk leerstoelen/Publiek_opdrachtgeverschap/bijeenkomsten/Webinar\%20Renovatieversneller\%20juni\%202020/Presentatie\%2 OWamelink\%20Webinar\%20Bouwstroom\%201\%20oktober\%202020.pdf (accessed on 20 July 2021).

28. Oorschot, L. De Apostel van de Verdichtingskerk Rijksbouwmeester Floris Alkemade en de Weilandvolbouwer en Woningbouwhoogleraar Peter Boelhouwer in Debat over de Woningopgave. 2020. Available online: https://research.tudelft.nl/en/pub lications/de-apostel-van-de-verdichtingskerk-rijksbouwmeester-floris-alkema (accessed on 20 July 2021).

29. Passive House. Available online: https:// passiefbouwen.nl/\&https://passivehouse.com/\&https://www.phius.org/ (accessed on 20 July 2021).

30. Lente Akkoord Zeer Energiezuinige Nieuwbouw. Available online: https:/ / www.lente-akkoord.nl/ (accessed on 20 July 2021).

31. Niyongabo-Paulussen, E.; Nuiten, P.; Cornelisse, M.; Valk, H. Scherpere eis Voor BENG 1 Heeft Wisselend Effecten. 2021. Available online: https:/ / www.lente-akkoord.nl/scherpere-eis-voor-beng-1-heeft-wisselende-effecten/ (accessed on 20 July 2021). 
32. Elkington, J. Towards the Sustainable Corporation: Win-Win-Win Business Strategies for Sustainable Development. Calif. Manag. Rev. 1994, 36, 90-100. [CrossRef]

33. Nuiten, P. (16 February 2018) Pieter Nuiten (W/E Adviseurs) over Grenswaarde MPG. Available online: https://www.lente-ak koord.nl/ pieter-nuiten-W-e-adviseurs-over-strengere-grenswaarde-mpg/ (accessed on 20 July 2021).

34. GPR. Available online: https:/ / www.gprsoftware.nl (accessed on 20 July 2021).

35. Sociale Verhuurders Haaglanden. Ruim 79000 Woningen Extra en Betere Verdeling in Regio Haaglanden. Available online: https: / / www.socialeverhuurdershaaglanden.nl/bouwmee-2/ (accessed on 20 July 2021).

36. Ten Teije, S. Bekende Woningbouwer Neemt Langzaam Afscheid van Beton en staal. Newspaper AD. 18-11-2021. Available online: https:/ / www.ad.nl/wonen/bekende-woningbouwer-neemt-langzaam-afscheid-van-beton-en-staal \{\}ab1b7537/ (accessed on 20 July 2021).

37. Convenant Green Deal Houtbouw. Available online: https://www.metropoolregioamsterdam.nl/wp-content/uploads/2021/1 0/Convenant-Green-Deal-Houtbouw.pdf (accessed on 20 July 2021). 